\title{
Photovoltaics - The Neglected Child of the Renewables
}

\author{
Teo Zalar, MSc \\ Head of sales - Photovoltaic power plants (Robotina d.o.o., Slovenia), External advisor - Renewable energy sources (Zastava \\ vozila AD, Serbia), External lecturer - Photovoltaics \& Sustainable development (Faculty of Economics, \\ University of Ljubljana, Slovenia \& SEE Institute, Serbia) \\ Email: teo@zalar.eu
}

\section{Doi:10.5901/mjss.2014.v5n20p2482}

\section{Abstract}

Upon decades of pompous talks about sustainable development $E U$ finally decided to put it into practice by fostering renewable energy sources (RES). After roughly half decade of rocketing development of photovoltaics (PV) technology and photovoltaic power plants (PVP) the majority of EU states cut down subsidies drastically and blocked completely (or almost) the further development of PVP, thus jeopardizing the sustainable development - environmental as well as economic achievements. While doing so there was a sharp lack of argumentated debate. The presented study thus aims to set a clear and argumented basis on which we should found our decisions about PV. The study shows that PV can help us to achieve sustainable development by helping to resolve some of the most crucial problems of humanity. Furthermore it has some crucial advantages over other RES and non-RES (thus having the potential to gain an important role in future energy portfolio) and it has also the potential to become price-competitive (grid parity). Unfortunately the young PV technology with its still high costs can still not compete with the unreal low prices of conventional energy sources as they do not incorporate costs of negative externalities. Because of this market failure market alone cannot make good use of all the PV potentials. This is why at this point the state (and other institutions) intervenes - solving limitations caused by market failure, with the aim to help PV technology coming to maturity, when it will be able to face the "unfair" competition of conventional energy sources on its own and continue its march to conquer its position in the energy portfolio. In conclusion - the findings above should be taken as the primary basis when setting our reviewing PV incentives policy and therefore before changing this policy we absolutely must bring related arguments to make founded decisions in accordance with a sustainable development paradigm - longsighted (over the border of our generation) and broad viewed (environment-economy-society).

Keywords: Photovoltaics, renewable energy sources, sustainable development, state incentives, feed-in tariff, grid parity

\section{Introduction}

"People's well-being, industrial competitiveness and the overall functioning of society are dependent on safe, secure, sustainable and affordable energy. The energy infrastructure which will power citizens' homes, industry and services in 2050, as well as the buildings which people will use, are being designed and built now [...] Transforming the European energy system is imperative for reasons of climate, security and the economy. Decisions being taken today are already shaping the energy system of 2050." (Energy roadmap 2050 - European Commission, 2012, pp. 3, 19)

Energy or new energy sources are those who have brought us the first two industrial revolutions and with them big socio-economic changes. Secure supply of big quantities of energy at affordable price has been the basis for imposing changes. Nowadays we harbor the same hopes about "green energies". Yet with the difference that today after one and half century of economic growth based on mass exploitation of fossil fuels (and roughly half century of exploitation of the other strongly contestable energy source - nuclear energy) we came in the position where energetics transformation is urgent already because of environmental issues. Delaying would mean not only "human problems" but also economic loss due to costs of climatic changes and pollution. On the other hand RES are a propulsive brunch which offers big economic/business possibilities by itself. Moreover, if we might feel that one and half century of fossil fuel exploitation is a long period, on the other hand we might see that structural changes in energetics take very long time, which is the reason for EU to plan half century in advance. However problems caused by fossil fuel exploitation are more and more burning and imminent - pretending not to see is not possible any more - actions have to be taken today.

This is the spirit in which the EU and the EU countries have begun to foster RES and amongst them PV. In just few years (everything has happened in 3 to 5 years) PV has reached exceptional results, which are much better than PV market actors had dared to predict. Within the end of 2012 we exceeded the frontier of 100 GW installed PVP capacity global (75\% of the total in EU and $31 \mathrm{GW}$ of the total only in 2012), which is equivalent to 16 big coal or nuclear power 
plants, allowing us to lower the annual $\mathrm{CO}_{2}$ emissions by $53 \mathrm{MIO}$ tons. In addition to the environmental aspect, there is the economic aspect also - a lot of jobs and companies sprang up - about 1,5 MIO direct and indirect employees (European Photovoltaic Industry Association, 2012c, p. 1-2, European Photovoltaic Industry Association, 2013, pp. 1-2). Eventually the rise of $\mathrm{PV}$ is the result of the implementation of the sustainable development concept in the practice of setting socio-economic policy within the consciousness of environmental, economic and social problems caused by the use of fossil fuels.

However within the passage from 2012 to 2013 the building of PVP has come to a collapse, with the most important EU PV markets experiencing a very sharp downturn in 2013 (e.g. Germany - 57 \%, Italy 70 \%) (European Photovoltaic Industry Association, 2014a, pp. 1-5) and with cases like Slovenia where PVP construction came nearly to a complete blockade (see also Figure 1). There were two reasons - a sudden and drastic cut down in state subsidies and the EU anti-dumping measures against China and their PV equipment producers. By doing so we jeopardized the sustainable development - the achievement of appointed and binding environmental goals along with economic achievements of the PV sector and broader. But on the other side there are countries like e.g. Japan, which after the Fukushima nuclear disaster is very well aware of the reality and inevitability of conventional energy sources problems and has being putting a great effort into RES, thus getting on the second position by newly installed PV power in 2013 (Japan 7 GW in comparison with whole Europe 11 GW) (European Photovoltaic Industry Association, 2014b, p. 9). Saying this it seems that EU countries - and Slovenia especially - cut down the subsidies without the needed consideration about the overall effects, perhaps in the excessive zeal of general cuttings in public expenditure in achieving the budget deficit and public debt criteria (Stability and grout pact) under EU and International Monetary Fund (IMF) pressure, maybe also because of the pressure from lobbies (especially energy intensive sectors, which have contributed a lot of money in the fund for "green subsidies" consequently facing competitiveness loss) and nonetheless possibly also because of the non-understanding of the PV tenor. It's very well that Samuelson and Nordhaus wrote that "economists can provide no scientifically correct answer to such questions" but the "study of macroeconomics arms us for the great debate" (Samuelson \& Nordhaus, 1998, p. 387), yet it seems that (especially in Slovenia, though with similar situation in other EU countries) we took the decisions of cutting the PV subsidies not only without scientifically correct answers but also without "arms" (arguments) and "debate".

Figure 1: Evolution of European PV annual installations 2000-2013 (MW)

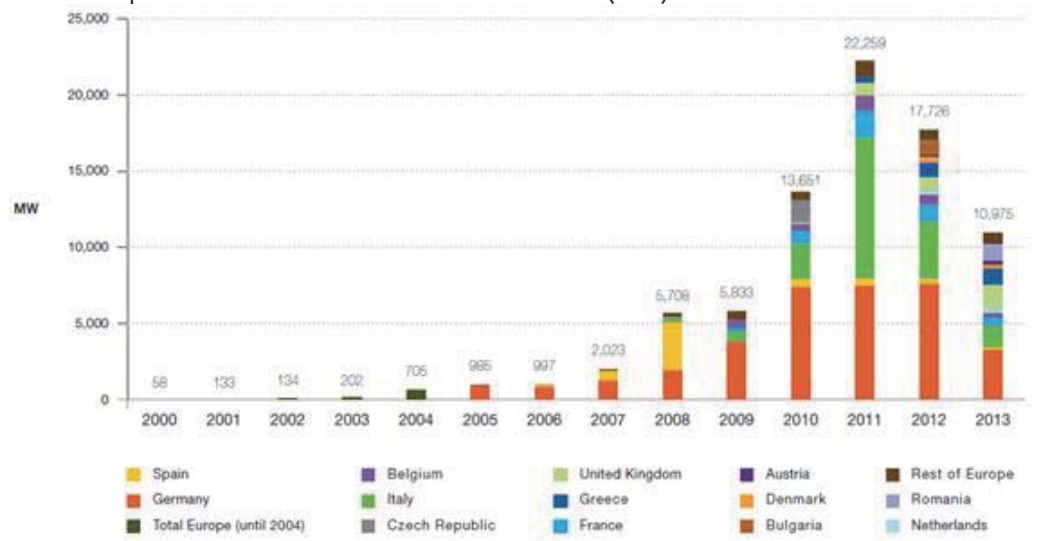

Source: European Photovoltaic Industry Association, GLOBAL MARKET OUTLOOK For Photovoltaics 2014-2018, 2014b, p. 21.

The sharp lack of argumented debate (with only partial, misleading and contradictory arguments) has paved the way for sudden and drastic changes in the PV policy - from contra to pro and back again, thus causing harmful business/economic fluctuations and standstills in environmental achievements. Therefore the objective of the study is to survey and clearly state the role of PV in sustainable development - with special regard to environment but also including its basic economic role/achievements. Further on this ground I will show how and why we (should) foster PV. At a letter stage (in the next study/article) this will be the basis to survey further into the economic role of PV, with a special regard to the possibility of using PV subsidies as a fiscal policy tool to foster the (stagnant) economy and to review the adequacy of past and present PV incentives policy, with the final goal to set 
recommendations for future PV policy. The main research queries for this first stage therefore are:

- which is the actual role of PV in sustainable development (in which way and extent it contributes to achieve sustainable development),

- which is the basic role of PV in the economy (achieved basic economic results and the potential for the future - installed PV power and price competitiveness or grid parity) and

- how and why we support PV (possibilities and commonly used measures, why PV needs to be supported and why it is worth being supported).

\section{Solar and Photovoltaic Energy and their Role in Sustainable Development}

After centuries of economic growth based on unbridled exploitation of natural resources and the society itself (firstly because of non-understanding, later on because we've been turning our blind eye to), the ever faster population growth, economic growth and technical development were the basis of the growing problems that couldn't be overlooked anymore. At the end of the day we don't have any other chance as to finally make ourselves conscious about the interrelations among economy, society and environment as well as the relations between present and future generations. Lastly on this basis we have to set our socio-economic policy, therefore to take action.

\subsection{Sustainable development and GPI (concept and measurement)}

Figure 2: Sustainable development - components

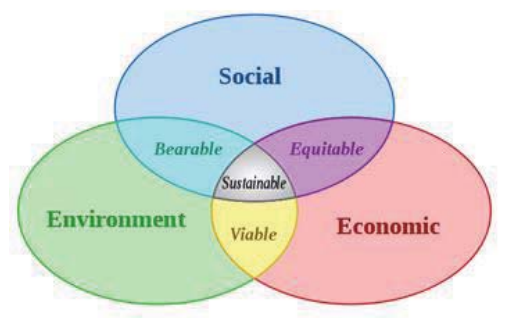

Source: Sustainable development, 2009.

Perhaps the most quoted definition has been coined back in 1983 by the Brundtland commission (formally the World Commission on Environment and Development - WCED) convened within the United Nations. Sustainable development "meets the needs of the present without compromising the ability of future generations to meet their own needs" for economic goods (and/including services), suitable living environment and social factors (Brundtland Commission, 2009; Sustainable development, 2009). The socio-economic policy paradigm of sustainable development represents the shift from a shortsighted and narrow view focused on product growth (accordingly GDP) to a longsighted view (over the borders of the current generation) considering development (considers all the important spheres of human life - economy, society and environment).

To put the paradigm of sustainable development efficiently into practice of setting socio-economic policy we need to incorporate its elements into our measuring tools. The Genuine Progress Indicator (GPI) aims to give the picture of welfare having in mind the possibility of keeping at least undiminished welfare in the next period and taking into consideration all three important spheres (economy, society and environment) (Genuine Progress Indicator (GPI), 2013; genuineprogress, 2013; The components of GPI, 2013). As the Nobel prize J. Stiglitz said: "GDP is an outdated measure, whose use leads to bad decisions", or the European Commission chairman J. M. Barosso "we cannot measure the challenges of future by tools from the deceased world" (genuineprogress, 2013).

GPI calculations on real examples show an alarming situation. Whilst the GDP p.c. of USA has been growing during the last 30 years, the GPI has been stagnant. Even more alarming is the study conducted by I. Kubiszewski in R. Costanza from the Australian university of Canberra. On the case of 17 countries, which represent more than half of global population and GDP, they found, that despite 35 years of stabile grout of their GDP p.c. the GPI reached its top in 1978 and has been decreasing ever since (Svijet nikad nije bio bogat kao te godine, 2013). According to this data sustainable development is clearly at risk. 


\subsection{Photovoltaics and other solar energy exploitation techniques}

Solar energy (SE) is the base source of almost all other energy sources on Earth. They are mostly just indirect exploitation of SE. Few utmost examples: winds - predominantly they are caused by convection as result of air warming by sunrays; biomass - almost all the biomass on Earth is hear owing to sunlight; fossil fuels - are nothing but very old biomass stocked under Earth's surface and slowly transformed. Simplified said - the sun energy is the one which propels humankind.

Figure 3: Solar energy exploitation techniques

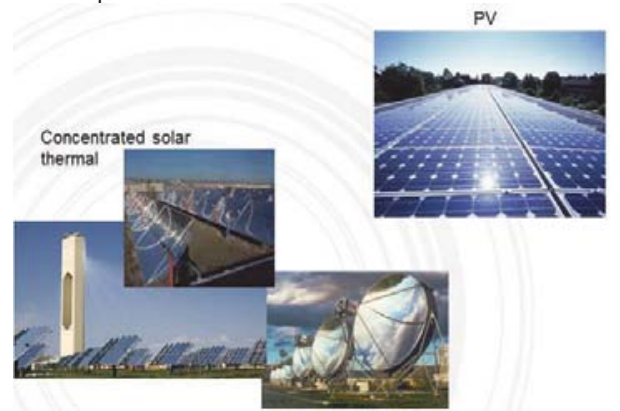

Source: Robotina d. o. o., Prodajno marketinška dokumentacija oddelka FV, 2013.

PV is just one of the possibilities to produce electricity from sunlight - each one with its specifics (Concentrating solar power, 2009; External combustion engine, 2009; Johnson, 2009, p 30-53; Nevada Solar One, 2009; Nevada Solar One, 2009; Our plants, 2013; Solar Energy Generating Systems, 2009; Solúcar Platform, 2009; Stirling Energy System Announces A New Division to Manufacture Suncatchers, 2009; Stirling Energy Systems set new world record for solar-togrid conversion efficiency, 2009; Stirling engine, 2009; Suncatcher, 2009; Wizard Power, 2009).

- Concentrated solar thermal (uses concentrated solar light):

- Turbine $^{1}$ - same as traditional thermo power plants (coal, nuclear etc.) it uses water steam to turn turbines and electro-generator, but they use the solar radiation to produce steam. Conversion efficiency: 20-25\%.

- parabolic trough (mirrors) system and concentrating linear Fresnel reflector

- heliostats or solar power tower

- Dish Stirling engine system - the gas inside is heated up on one side (e.g. with sunlight) and cooled down on the other, a consequent gas expansion/contraction makes the pistons move and turns the electrogenerator ${ }^{2}$. Conversion efficiency: ca. 30 \% (the highest amongst commercially available solar systems).

- Photovoltaics - is the only direct conversion of solar energy into electricity and the only without moving parts. The PV cell produces electricity when it's been hit by light (electro-magnetic waves). When the photons hit the PN-junction (PV cell) the electrons are knocked loose from their atoms, allowing them to flow through the material to produce electricity. Conversion efficiency: ca. $16 \%$ (for crystal silicon cells - the most commonly used today).

Although PV seems a completely new and different technology, the PV effect has been discovered already back in 1839 by the French experimental physicist A. E. Bequerel. But its pace of development and implementation has been very slow until just few years ago, when state incentives came to help it (European Photovoltaic Industry Association, 2013, pp. 5-6, 13, 15, 18; European Photovoltaic Industry Association, 2014b, p. 9):

- 1880 - The first real PV cell (C. Fritts \& W. Siemens - foreseen the long-run potential of PV) - $1-2 \%$ efficiency - it did not break thorough as an energy source (used only as light sensor)

- $1904-$ A. Einstein gave us the understanding of PV effect (in 1921 he got the Nobel prize for physics)

- 1940-1950 - Monocrystalline cells with 4\% efficiency appeared:

- They were still expensive - unsuitable for mass production of energy

○ Mainly used for special purposes (e.g. 1958 the first satellite powered by PV)

- 70 's-80's - More serious research and increase in production and use

${ }^{1}$ Note - there is no uniform term for this group.

2 The Stirling engine is a type of external combustion engine same as the steam engine and it was invented already back in 1816. 
○ First big PVP: 1 MW + 6,5 MW Arco (California, USA)

- Main drive: oil crisis

- Nowadays (after 2009 EU directive on the promotion of RES - the crucial point that boosted the global development of PV - see also Figure 4)

- Total installed power of PVP in the world - more than $138 \mathrm{GW}$

- EU leads by installed PV power, but after sharp FIT cuts and anti-dumping measures has started loosing its primacy (see also Figure 5 )

- China produces the vast majority of PV panels (80\% of panels installed in EU in 2012)

$\circ$ Main drive : ecology and sustainable development (with state incentives)

Figure 4: Evolution of global PV cumulative installed capacity 2000-2013 (MW)

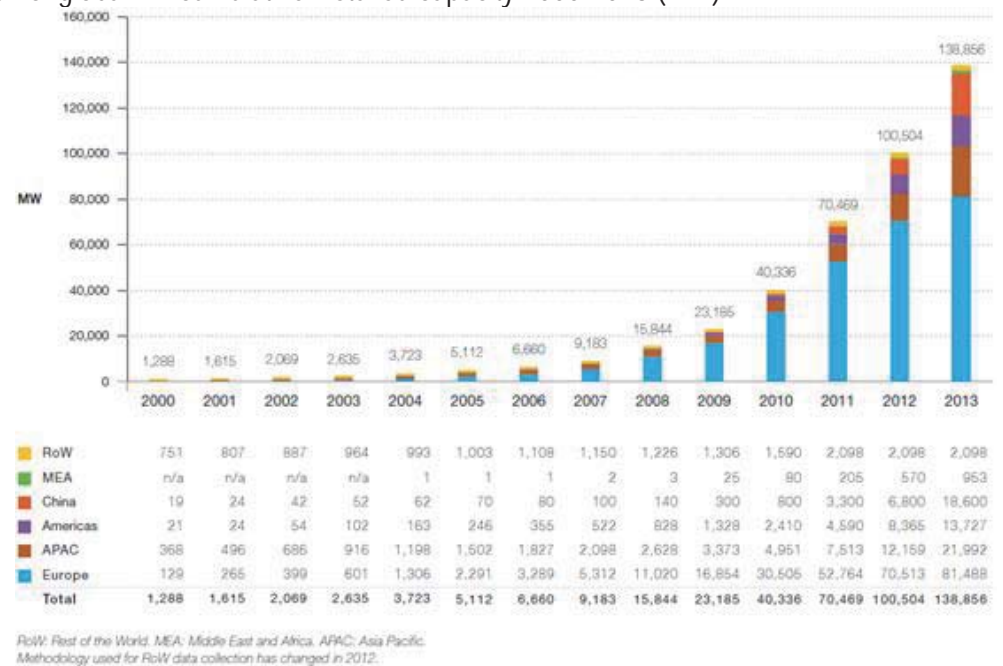

Source: European Photovoltaic Industry Association, GLOBAL MARKET OUTLOOK For Photovoltaics 2014-2018, 2014b, p. 17.

Figure 5: Evolution of global PV annual installations 2000-2013 (MW)

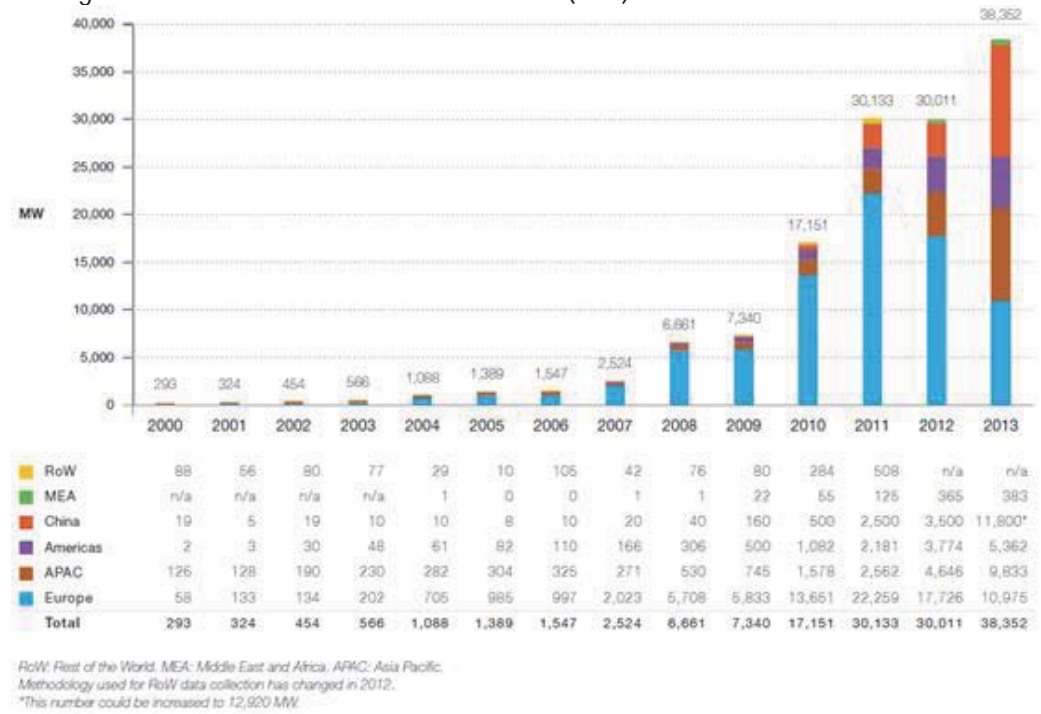

Source: European Photovoltaic Industry Association, GLOBAL MARKET OUTLOOK For Photovoltaics 2014-2018, 2014b, p. 18. 


\subsection{The potential of solar energy and photovoltaics}

Oftentimes we tend to underestimate the sunrays potential. But as we saw it is the base source of merely all the other energy sources on our planet and estimations prove its great potential (Lenardič, 2009, pp. 1-11; Sun, 2009).

- The Sun represents $99 \%$ of the mass of our solar system and provides it with light, heat and other forms of SE

- The Sun is brighter and has more mass than $95 \%$ of the stars in the Milky way (our galaxy)

- The Sun's energy derivates from fusion reactions in its core

- It radiates with the power of $3,8 \times 10^{26} \mathrm{~W}$

- It is a young star with 4,6 MIO years and it will shine with the same force for another $5 \mathrm{MIO}$ years

Figure 6: RES potential - world
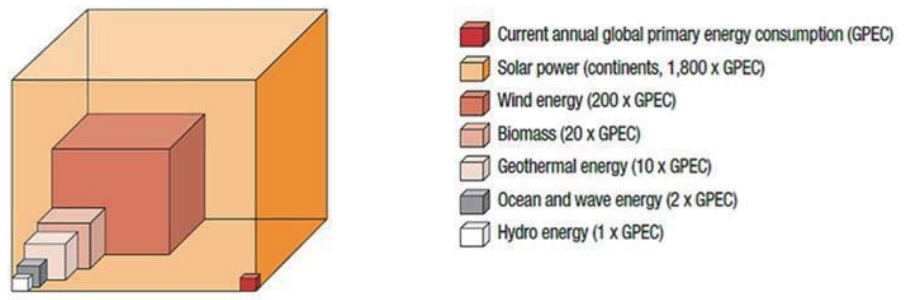

Source: CdTe PV - Leading the Way to Sustainable Solar Energy, 2013.

In practical terms this means that the overall solar energy that falls on the Earth's surface exceeds the humankind needs for all the primary energy (not only electricity) by 6000-7500 times (Papler, 2012, p. 72) therefore it is virtually unlimited. Let me give you a few more comparisons.

- In one hour enough energy falls on the Earth's surface to cover the annual needs ${ }^{3}$ (Solar Energy, 2013; Solar for Europe's future, 2013).

- Covering 0,7 \% (by some sources only 0,34 \%) of Europe's land surface with PV panes, we would produce enough electricity to cover the European needs (Global solar resources, 2013; Key Facts \& Figures, 2013).

- Covering $4 \%$ of the most dry desert surface with PV panes, we would produce enough electricity to cover the global needs for all the primary energy (Global solar resources, 2013).

Figure 7: Solar irradiation and PV production potential - Europe

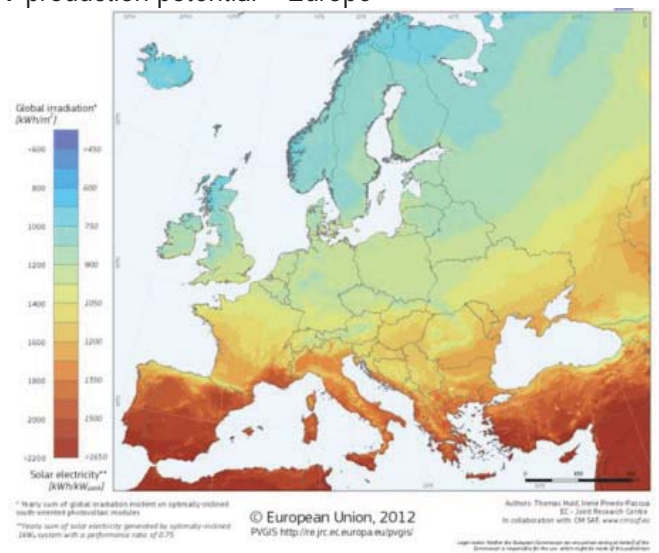

Source: Country maps, 2013.

${ }^{3}$ The sources don't mention the details, but from the context I can assume that it refers to the PV and the coverage of needs of electrical energy. 
Despite the great potential of the sun humankind still produces ca. $80 \%$ of its electrical energy from non-RES ${ }^{4}$ and less than $1 \%$ of the electricity demand is covered by PV (in EU $3 \%$ with Italy having the highest share with 7,5\%) (European Photovoltaic Industry Association, 2013, p. 46; European Photovoltaic Industry Association, 2014b, p. 52; FAQs: Renewable energy, 2014).

\subsection{Future energy portfolio and photovoltaics}

I firmly believe that in future same as today we will use a combination of energy sources (Barteau, 2009, pp. 1-28), each one with its pro end contra or with its specifics. E.g. operating time (daytime, good/bad weather, windy etc.), storage possibility (dams, molten salt, batteries, hydrogen and fuel cells etc.), availability of the source (sun potential, wind potential, hydrogen for fusion, traditional nuclear sources, coal, geothermal sources etc.), start-up time, renewability, pollution etc. The different sources summed up will give us a coherent, functional and sustainable energy system that will meet all our energetic and sustainability needs. In time also new sources will arise like e.g. fusion energy, JTEC (Johnson thermoelectric energy conversion system), space-based solar power (solar satellite) etc., but it will take decades. E.g. EU mentions the fusion energy as a possibility for the future, but its possibilities will probably (nothing but) clarify within the prospective of the EU energy program till 2050 (European Commission, 2012, p. 13). On the other hand we have to take actions today, therefore we must make good use of what is available at this moment.

SE advantages over other energy sources:

- Does not require any type of fuel - simply uses the solar radiation which falls on the Earth anyways

- Is a renewable energy source (or almost unlimited potential)

- Is a "green source" - it works without noise, pollution or radiations

PV advantages over other SE:

- Available virtually anywhere (at all geographical latitudes) - require little light to operate and it has negative temperature coefficient (the cooler the more electricity PV produces - this characteristic additionally balances the effect of lower irradiation on higher latitudes)

- Has the greatest potential amongst all SE (Ranking the renewables, 2009)

- Does not require water to operate (in contrast with Concentrating solar thermal power systems for cooling)

- Completely scalable (from milli-watts to mega-watts)

- Almost without maintenance

- Lifetime - more than 30 years $^{5}$

- Enables local (decentralized) energy production - therefore disburdens the grid, diminishes energy transfer losses and allows local and individual energy autonomy

- Building integration - no need to occupy natural surfaces

- Versatile usage (power plants, satellites, cars, street lighting, buoys, lighthouses, parking automats, calculators etc.)

- The production peak usually coincides with overall grid peak consumption - which lowers the electricity peak price (e.g. in Germany up to 40 \%) (Solar for Europe's future, 2013; Resnica o sončnih elektrarnah, 2013)

- Recycling is provided by associations (e.g. PV Cycle) free of charge - as valuable materials can be recuperated from the panels (e.g. silicon, aluminium, glass etc.)

PV have also very good Life Cycle Analysis (LCA $)^{6}$ performances and they are likely to improve further as PV is still developing (European Photovoltaic Industry Association, 2012a, pp. 1-2; European Photovoltaic Industry Association, 2012b, p. 1; European Photovoltaic Industry Association, 2012e, pp. 1-2):

- Carbon footprint - very low (see also Figure 8)

- Carbon footprint: $16-32 \mathrm{~g} \mathrm{CO}_{2 e q} / \mathrm{kWh}$ (fossil fuel power plants 300-1000 $\mathrm{CO}_{2 \text { eq }} / \mathrm{kWh}$ )

- Carbon footprint has decreased in 10 years by $50 \%$ (higher panels efficiency, savings of material, improved production)

- In other words - for every kWh of electricity produced with $\mathrm{PV}$, we diminish the $\mathrm{CO}_{2}$ emissions by $0,5 \mathrm{~kg}^{7}$

\footnotetext{
${ }_{4}^{4}$ Even more if we consider all the primary energy - ca. $87 \%$.

${ }^{5}$ Estimation only.

${ }^{6}$ The LCA is a standardized method of assessing the overall impact of a technology over all its life cycle - from row material, manufacturing and transportation up to construction, utilization and recycling.

7 This is the most commonly used data - date vary in accordance to which energy source we make the comparison.
} 
- Water footprint - very low (see also Figure 9 and Figure 10)

○ Water withdrawal8: 0,8-1,9 I//kWh (conventional power plants 1,2-230 l/kWh)

○ Water consumption?: $0,1 \mathrm{l} / \mathrm{kWh}$ (fossil fuel power plants $0,75-75 \mathrm{l} / \mathrm{kWh}$ )

- Energy payback time - short

- Energy payback time: 0,5-1,4 years (depending on technology and location)

- Lifetime of PVP is more than 30 years - therefore produces net electricity ca. $95 \%$ of its lifetime

Figure 8: CO2eq ( $\mathrm{g} / \mathrm{kWh}$ ) emissions for electricity generation

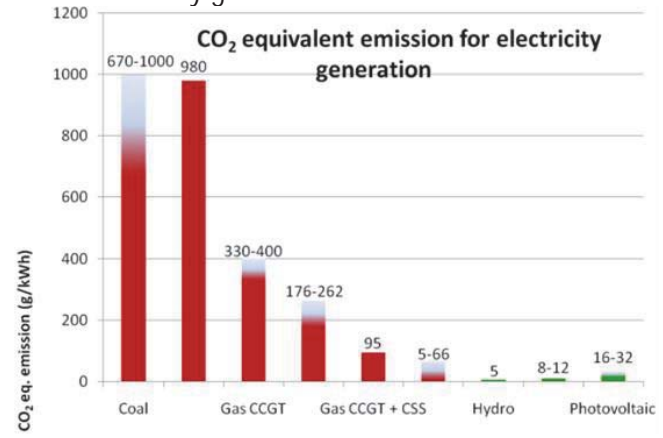

Source: European Photovoltaic Industry Association, The Carbon Footprint, 2012a, p. 1-2.

Figure 9: Water withdrawal (l/kWh) for electricity generation

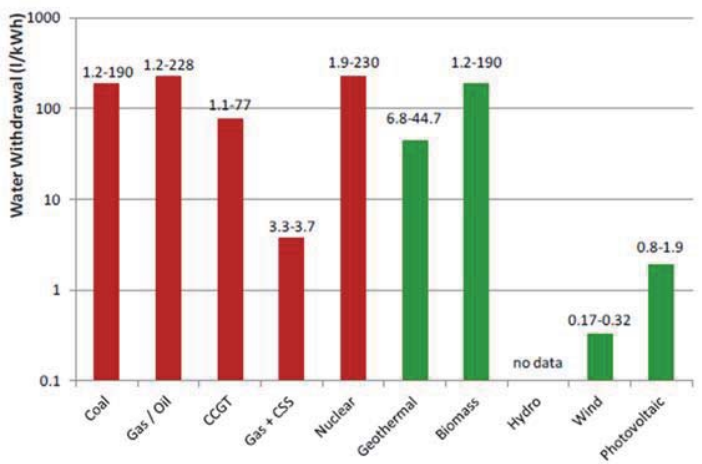

Source: European Photovoltaic Industry Association, The Water Footprint, 2013e, pp. 1-2.

Figure 10: Water consumption (l/kWh) for electricity generation

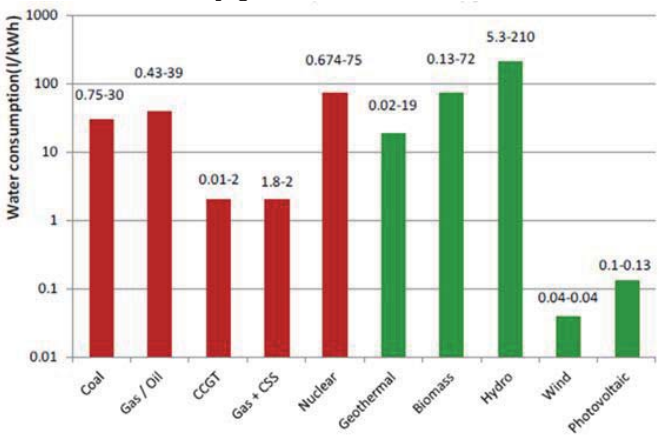

Source: European Photovoltaic Industry Association, The Water Footprint, 2013e, pp. 1-2.

${ }^{8}$ Removed from the ground or (temporarily) diverted from a water source for use.

${ }^{9}$ Evaporated, transpired, incorporated into products or crops, or otherwise removed (long-term) from the immediate water environment. 
PV has some crucial advantage over conventional energy sources and RES also. Therefore it can play an important role in the future energy portfolio(s), which exact composition(s) will be dictated by the needs and possibilities both global and local.

\subsection{Photovoltaics and sustainable development}

In the previous chapter I showed the basic technical reasons that will allow PV to gain an important role in the future energy portfolio. These same reasons give us the possibility to use PV to reach the goals of sustainable development. Having this in mind, lets make a turn at the beginning of our story and take a look on the implications of PV technology on sustainable development. In the year 2003 the Nobel prize Richard E. Smalley (Humanity's top ten problems, 2013) has identified the 10 most crucial problems of humanity for the next $\mathbf{5 0}$ years (listed from the most burning one): Energy, Water, Food, Environment, Poverty, Terrorism \& war, Disease, Education, Democracy and Population.

Smalley's definition of the humanity's crucial problems has all the elements which I recognized at the beginning in defining sustainable development. It is a long-run approach beyond the borders of current generation and it takes into consideration all the important spheres of human life - social, environmental and economic. Therefore we can take Smalley's definition of crucial problems as a basic operative plan of achieving sustainable development in the next 50 years.

PV helps us to achieve sustainable development by helping resolve 5 out of these 10 problems. As we saw PV is first of all a clean and renewable energy source. Hence it follows that PV can help us to resolve problems of energy supply, keeping clean water sources and general environmental problems. Moreover it can help with food supply problems caused by bio-fuels in the food-chain and also to soothe international frictions due to fight for rare and polarized energy sources (especially fossil fuels). This was the basis on which states (and other institutions) have begun to foster the development of PV.

\section{Photovoltaics - Incentives and Investments}

\subsection{Investments - photovoltaic power plant as a business (investment) decision}

Due to their specifics PVP are not suitable for state investments. The state often invests in centralized power plants, but it is hard to imagine the state to invest in a scattered net of small power plants. Furthermore scattered (local) electricity production and possibility to use small roofs (existing artificial surfaces) are PV advantages. It is more reasonable for the state to help along the private investments in PV with subsidies (we can talk about a kind of indirect state co-investments) and to hand over to individuals (investors, roof owners, roof lessors or renters etc.) and to the market the investment micro-optimization (for each specific case).

Investments in PVP are thus prevalently in the domain of the private sector and therefore they are above all a business decision. But even PV great potentials for sustainability by itself are not enough to make full use of this potential. More precisely they are not enough for PV to flourish spontaneously on the market. Every activity which is not within the state consumption or investment is subjected to the rules of market, business and profit. The market acts like a sieve, which lets through what is economically justified - products or investments which give risk adequate profitability in a time perspective that market subjects perceive as reasonable. This sieve is not without faults - we call them market failure. Today the problem subsists in first place as a to high PV electricity price in comparison to other - especially conventional - energy sources. This in turn generates some other implications (they are explained more in detail in the next chapter). States and supranational institutions (e.g. EU) here act in function of correcting the market and with various kinds of supports do take care that PV and PVP are good investments with risk adequate profitability in an acceptable timeline. This is the first and the most important reason for privates to invest in PV. Nevertheless it is possible to additionally identify few minor factors for private investments in PVP - energy independency, prestige and modernity and also ecology as a marketing grip.

\subsection{Incentives - reasons}

States (and other institutions - national, international, supranational) take steps to set up a suitable investment environment where PV investments could flourish, because they are aware of two things - on one hand PV is advantageous in the long-run (can help us to achieve sustainable development, has the potential to be a key player in the future energy portfolio and it has the possibility to become price competitive) but on the other hand there is the 
market failure (market would not develop PV by itself).

The market failure here starts in form of a too high PV electricity price in comparison to conventional energy sources. In these circumstances private investors will not be willing to invest if we have to rely on market forces only. The following reasons arise (in absence of a broad state guided policy):

- Positive investment results are too uncertain. We could probably hardly find any singular investor capable of reaching the critical mass of investments to develop PV technology to the maturity, so a vast number of private investors must get involved. A singular investor thus can't be sure if the critical mass of such investments will be achieved.

- Positive investment results are anyways too distant in time. This might cause:

○ liquidity problems

- principal-agent problem - managers might face the problem of not being understood by the owners in the attempt of a long-run business/investment (Samuelson \& Nordhaus, 1998, pp. 177-178; Tajnikar, Brščič \& Bukvič, 1998, p. 6) ${ }^{10}$

- There is no instrument for the investor to secure the fruits of his investment (the mature state of PV) want be picked also by others.

- Positive externalities - the lower costs of pollution and climatic changes (due to substitution of conventional energy sources with PV) will be usufructed by all citizens. This is why here the co-investor is the state (indirectly - via subsidies) - therefore all citizens (indirectly - via taxes).

The sources of this high relative price of the PV energy are two. On one side there is the still high cost of the still young PV branch/technology per se (will be explained in the next paragraph). On the other side there is the unreal low cost/price of conventional energy sources. If the market would be capable of incorporating the costs of negative externalities (e.g. pollution, climate change and healthcare costs, GDP loss etc.) in the energy (product) price, than the process would be market automatic (in the majority of cases ${ }^{11}$ ). But market subjects simply avoid every cost which is not directly linked to their products. E.g. if decades ago the price of asbestos roofs would have incorporated the costs of medical treatments for asbestosis and the GDP loss related with increased illness and mortality, then the asbestos roofs would probably be so expensive, that they would never break through on the market. In this case the market automatism would be enough to protect the long-run interest of the society on all its levels - it would be enough to achieve sustainable development. But the market simply does not work this way, which is a form of market failure. The market puts every product/technology on the balance, with benefits on one scale and costs on the other. But weighting the fossil fuels some costs (negative externalities) are simply not being put on the balance. The comparison therefore is neither real nor long-run sustainable - someone and sometime will have to pay the cost that we suppressed or turned our blind eye to - either in a way or another. Again - this is exactly what we aim to avid with sustainable development - namely partial consideration of issues and base today development (or better to say growth) on overthrowing the costs on future generations. This is why we need state interventions to foster PV.

We already saw how PV helps sustainability and its potential to be part of the future energy portfolio. The last issue remaining to take a look at is the PV potential to become price competitive in comparison with conventional (electrical) energy sources. As said the price of the PV electricity is still high per se, because PV is still a young technology and still has to evolve in its mature phase with lower prices ${ }^{12}$. Eventually PV electricity price will diminish enough to be able to compete alone (without state incentives) with unreal low conventional energy prices. The moment when PV will reach the grid parity is not so far anymore. Figure 11 shows us the concept of grid parity for a fictive and simplified case of France and Spain. Grid parity is achieved when the PV electricity price (without incentives) reaches the grid electricity price ${ }^{13}$. PV electricity prices are different among countries due to difference in PVP prices, solar irradiation (which defines production potential) and also PV market maturity (which affects the cost of capital via perceived risk within banks) (European Photovoltaic Industry Association, 2012d, pp. 1-2). Similar reasons lie beneath the falling PV price curve - falling of PVP price due to technology maturity and PV market maturity. Grid electricity curve can be different by countries and consumer groups, but has a common characteristic - it tends to rise (slightly) in time.

\footnotetext{
10 It is one of the possible forms of the principal-agent problem.

${ }^{11}$ In some cases of new technology at its young stage (with high price per se) some government intervention to help the development of this technology into its mature phase, might still be needed.

12 Lower electricity price can derivate from a lower price of PVP or from a higher efficiency of PVP.

${ }^{13}$ This definition of grid parity is simplified as it can vary if we e.g. examine only the household segment or else, moreover different concepts can be found. Presented is also a simplified example of grid parity - measuring in practice brings us much more complications - but this simplified example is enough to help us understand the basics of the concept.
} 
Finally we can see, that grid parity will be achieved - in France in 2016, in Spain already in 2013. When grid parity will be achieved the principal obstacle for the spontaneous development of PV will vanish, therefore state incentives (as we know them today) will not be needed anymore.

Figure 11: Grid parity concept (fictive case)

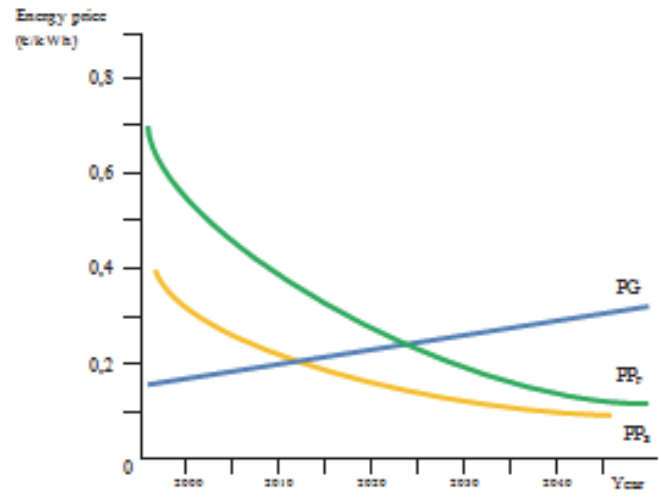

Legend:

PG - Grid electricity price

$\mathrm{PP}_{\mathrm{F}}-\mathrm{PV}$ electricity price in France

PPs - PV electricity price in Spain

Real date forecast on grid parity (see Figure 12) says that in some countries grid parity will be soon achieved. A piece of information from field for illustration - before anti-dumping measures (introduced in 2013) PVP without state subsidies has begun to arise on the south of Italy - which is congruent with the forecast in the table below.

Figure 12: Detailed breakdown of achieving the PV grid parity in the residential segment in the target countries for $50 \%$ and $90 \%$ of the probability

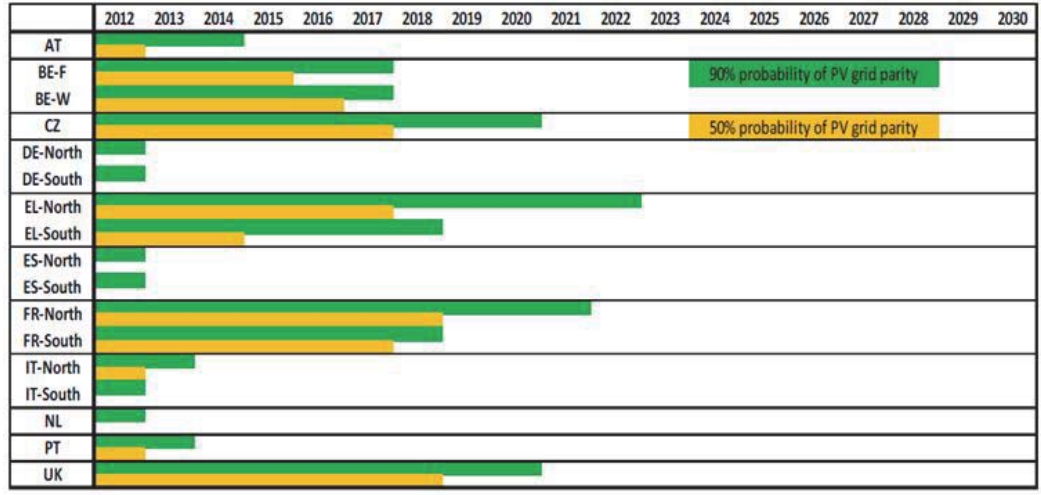

Legend: AT=Austria, BE-F=Belgium-Flanders, BE-W=Belgium-Wallonia, CZ=Czech Republic, DE=Germany, EL=Greece, $\mathrm{ES}=$ Spain, FR=France, IT=Italy, NL=The Netherlands, PT=Portugal, UK=United Kingdom

Source: European Photovoltaic Industry Association, PV PARITY Project: European consortium highlights competitiveness of Solar Photovoltaics (PV) in 11 EU countries, 2012d, pp. 1-2.

To sum it up - PV is a good direction in long-run, as it will path the way to sustainable development and has also the potential to gain an important role in future energy portfolio and to become price competitive. Unfortunately at this moment it still cannot compete by itself with conventional energy sources, because of the still high relative price in comparison with the unreal low price of conventional energy sources which do not incorporate negative externalities costs. The market alone cannot resolve this divergence, therefore all the potentials of PV would not be used. This is why 
at this point the state (and other institutions) intervenes - solving limitations caused by the market failure, thus to help PV coming to maturity, when it will be able to face the "unfair" competition of conventional energy sources and continue its march to conquer a position in the energy portfolio.

The purpose of incentives (subsidies) therefore is not the constant financing of the PV, but to help the PV to come into the point where it will not need this kind of help anymore. Although I believe that even constant support in the extent of denied cost of negative externalities in conventional energy pricing would be justified, as we have to pay this cost sooner or later anyways. Moreover, although probably no one would be able to express it in terms of money, health and (living) environment are goods per se with its own value, which loss has to be added to the elementary negative externalities of non-RES in form of climate change, medical treatments, GDP loss etc. However in the case of PV this constant financing is not needed and the argument of some PV opponents "why we should pay this higher electricity price" has been busted. PV electricity price has fallen drastically in just few years and grid parity will be achieved soon. This is thanks to the very same state incentives that have set in motion the investment cycle in PV and PVP and in turn made possible economies of scales, R\&D investments and competition. All together have already born fruits in the form of better technologies and lower priced of PVP and PV electricity. E.g. the price of PVP ${ }^{14}$ has fallen from 5-6 $€ / W$ of installed power in 2008/2009 to somewhere around 1,0-1,5€/W in 2013/2014. Therefore today prices are roughly $1 / 5$ of those from $4-5$ years ago. So even if we look it through a very narrow economic view - state incentives to PV make sense. The market cannot do it by itself - state support is needed and reasonable!

\subsection{Incentives variety}

Supranational institutions set the basis for national policies to overcome the problem of short-to-medium-term competitiveness loss (relative to other countries) due to charging extra costs of financing RES state incentives (or negative externalities of non-RES) on the price of products. This is done through setting common policy/obligations for the states. EU states have obligations toward EU, EU in turn has obligations toward the rest of international community within the Kyoto protocol (DIRECTIVE 2009/28/EC OF THE EUROPEAN PARLIAMENT AND OF THE COUNCIL of 23 April 2009 on the promotion of the use of energy from renewable sources and amending and subsequently repealing Directives 2001/77/EC and 2003/30/EC. Official Journal of the European Union, 11, L 140, 16-62; Kyoto Protocol, 2013; Declarations and Reservations by Parties - Kyoto Protocol, 2013; Status of Ratification of the Kyoto Protocol, 2013). EU state obligations are known as "20-20-20 goals" till the year 2020. Synthesized - EU would like to reduce the greenhouse gasses emissions by $20 \%$ (in comparison to 1990), increase the RES share in energy consumption to $20 \%$ and increase energy efficiency by $20 \%$ (energy consumption decrease in comparison with projections) till 2020 (2020 Targets, 2013; The EU climate and energy package, 2013). Practical implementation is done through individual binding goals for states e.g. Slovenia has to reach $25 \%$ of RES till 2020.

This is the basis on which states and other institutions can and must build their PV (and RES in general) support policy. Incentives are about correcting the mentioned balances for energy sources in such way, that market can perceive the PV as a good business opportunity. We can do so either by increasing the unreal low costs of non-RES or we can decrease the still (too) high PV costs (optionally by increasing their income side). Along with this we should solve also non-economic obstacles. In practice we can find a vastness of executional solutions. Normally a mixture of measures is used. I will show the most frequent concepts.

State incentives are the most important (by amount) for direct investments in PVP.

- Non-economic (have special significance - set the "rules of the game" - define time, possibilities, risks and costs for investors in PVP - so they are absolutely needed for the FIT to be able to work out at all15)

○ Promotion and awareness-raising

- Law and regulations (grid connection rules, general law and PV specific laws)

- Technical measures (measures for grid development and grid connection, smart-grid solutions, energy storage etc.)

- Economic

- Green certificates, taxes on $\mathrm{CO}_{2}$ emissions etc.

- Direct financial incentives

- Subsidized credits (subsidized interest rates)

\footnotetext{
14 Turnkey price in Slovenia.

15 Slovenia is a perfect example as PVP rocketed out only when the non-economic obstacles were solved, while (high enough) FIT was present there already 1-2 years before.
} 
- Grants

- Feed-in tariffs (defined as subsidy in €/MWh of electricity produced) - this is the most common and the most important kind of support by amount in the EU countries

Nevertheless we can find also direct EU incentives (not directed to states but to the business sector):

- EU funds for projects related to:

○ R\&D

- Awareness-raising

- Education

- Removal of other non-technical and technical limitations (e.g. grid connections, PV energy selfconsumption, state specific FIT optimization etc.)

- PV linked initiatives (e.g. incentives for electric cars charge stations, development of electricity storage techniques, smart-grid solutions etc.)

There are also initiatives of non-governmental sector which comes in the form of institutions, associations and projects which in addition to the previously mentioned motivations has also business related motivations:

- EPIA (European Photovoltaic Industry Association), EU ProSun etc.

- National Association of PV industry (Slovenian ZSFI, German BSW etc.)

- Universities with their departments and laboratories

- Companies with their own initiatives and development departments

- Projects: PV Parity, SolarRok, PV Legal, PV Grid, REserviceS, metaPV, Twenties, IGREENGrid and Grid4EU, Za zeleno prihodnost s soncem, Za zeleni razvojni preboj! etc.

\subsection{Investment environment vs. sun potential and the meeting point of state incentives and private investments}

Figure 13: Installed PV power per capita - World and Europe (2012; W/habitant)

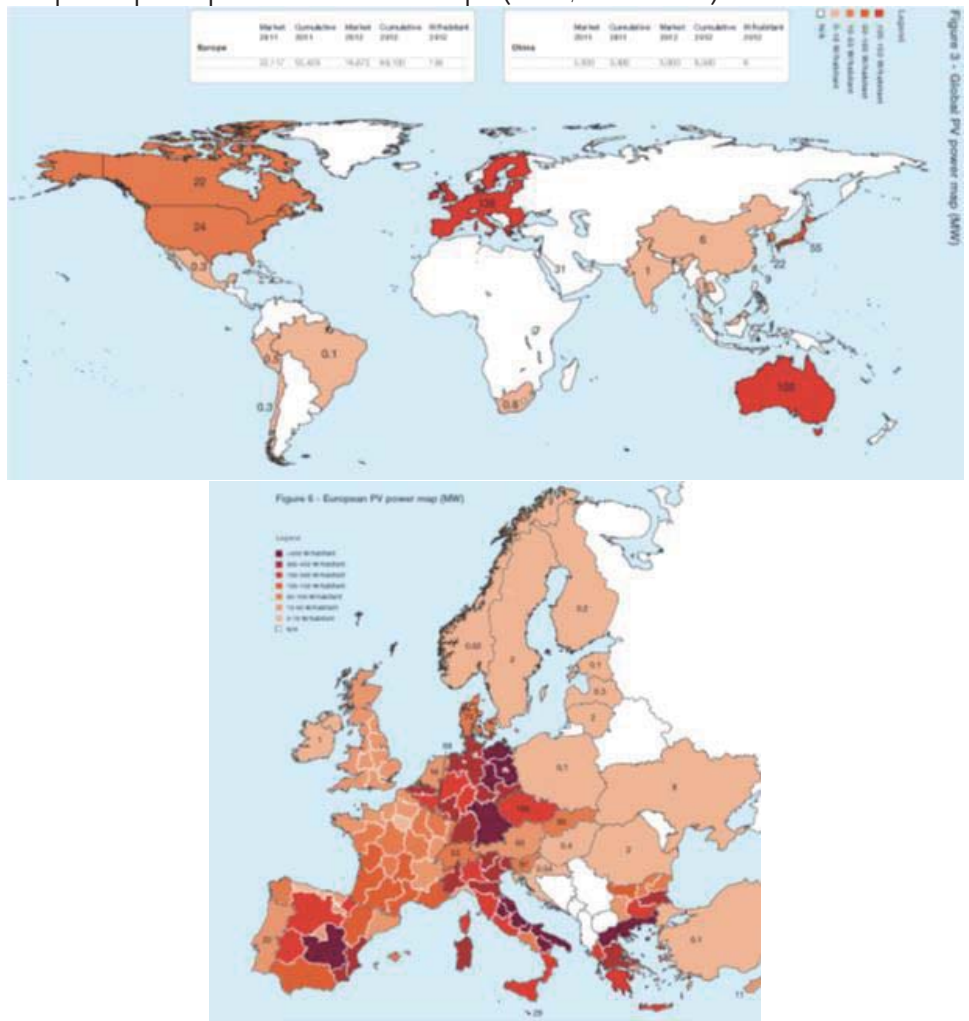

Source: European Photovoltaic Industry Association, Global Market Outlook For Photovoltaics 2013-2017, 2013b, pp. $15,18$. 
A quick glance at the graphs of the solar potential (Figure 7) and the actual installed PV power (Figure 13) tells us that solar potential alone cannot drive the PVP development. Other factors are important also - in the first place state economic and non-economic incentives with all their implications (grid connection possibilities, possibilities to use or market your PV energy, needed time, money and risks to build a PVP etc.), but other factor like grid electricity price etc. also. All factors together form the investment environment. Higher solar potential means lower FIT needed to have an analogous investment environment. For a better illustration - an optimally set PVP in central Europe (e.g. Ljubljana $1.100 \mathrm{kWh} / \mathrm{kWp} / \mathrm{year}$ ) produces roughly $37 \%$ less electricity than in the equatorial belt (e.g. Addis Ababa -1.760 kWh/kWp/year).

Table 1: Potential (expected) production* - comparison of locations with different geographical latitudes

\begin{tabular}{|l|c|c|c|c|}
\hline City (country) & $\begin{array}{c}\text { Expected yearly production } \\
(\mathbf{k W h} / \mathbf{k W p})\end{array}$ & $\begin{array}{c}\text { Difference from } \\
\text { Addis Ababa } \\
(\%)\end{array}$ & $\begin{array}{c}\text { Optimum } \\
\text { inclination } \\
\left({ }^{\circ}\right)\end{array}$ & $\begin{array}{c}\text { Optimum orientation } \\
(\text { azimuth) } \\
\left(\mathrm{S}=0^{\circ}, \mathrm{E}=-90^{\circ}\right)\end{array}$ \\
\hline Addis Ababa (Ethiopia) & 1.760 & 0,0 & 13 & -2 \\
\hline Palermo (Italy) & 1.500 & 14,8 & 32 & -2 \\
\hline Ljubljana (Slovenia) & 1.100 & 37,5 & 34 & -2 \\
\hline Moscow (Russia) & 874 & 50,3 & 36 & 0 \\
\hline
\end{tabular}

Notes: * Potential or expected yearly production per $1 \mathrm{kWp}$ of installed power at optimal settings (inclination and orientation) for the individual location.

Source: Zalar, 2013, p. 27.

A great deal of the investment environment factors are in the competence of the state (and other institutions), which actually has the power to establish a suitable investment environment as a whole, thus allowing investments in PV and PVP to bring suitable profitability at an acceptable level of risk within a reasonable timeline. Therefore this is the meeting point of the state (in broader terms) with its interventions on one side and business sector with its investments on the other side, with the final goal of achieving sustainable development.

\section{Conclusion}

"Using renewable energy is one effective way of making our energy supply more environmentally friendly [...] It is thus the surest means we have of both reducing emissions and improving the security of our energy supply [...] Renewable energies also have huge potential to boost Europe's industrial competitiveness. Developing new sources of low-carbon energy is crucial to avoid the massive costs of climate change and pollution, and keeping Europe at the forefront of such developments is crucial for the economy" (Renewables make the difference - European Commission, 2011, pp. 4-5)

Thoughts written by the European Commission show a clear picture of how well aware EU is about the importance of energy supply. After one and half century exploiting fossil fuels and other environmentally contestable sources like nuclear energy, the problems have become so evident and consequences so serious and imminent, that pretending ignorance was simply not possible any more. The new socio-economic paradigm is named "sustainable development" and it has two important characteristics that clearly distinguish it from previous paradigms. Firstly it is based on intergenerational (long-run) view point and secondly it considers all the important spheres of human life - environment, economy and society. PV is one of the means we can or have to use to achieve sustainable development. Actually in the spectrum of energy sources PV is amongst the most suitable, since it can help us to resolve 5 out of 10 most crucial problems of humanity in this half of century - energy supply, clean water, general environmental issues, food supply and soothe international frictions. Moreover PV has the potential to become price competitive in comparison to conventional energy sources and it has some crucial advantages in comparison to conventional sources as well as to other RES, which paves the way for PV to contend its position in the future energy portfolio.

This was the basis on which the EU and the EU countries have committed themselves to formally binding goals known as 20-20-20 goals till 2020, which includes also the achievement of $20 \%$ of RES. To achieve this goal in the current situation - where PV (with similar situation for other RES) still cannot evolve on the market by itself, because of relatively high PV prices (young technology) along with unreal low prices of conventional sources (don't incorporate negative externalities costs) - states begun to stimulate PV. Market failure is the reason we cannot rely on market alone to reach this objective. Due to their specifics PVP investments are mainly in the domain of the private sector, with the 
state in the role of a kind of indirect co-investor in the form of subsidies along with other measures to produce a suitable investment environment, with the goal of setting into motion the investment cycle, consequently economies of scale, R\&D investments, competition and finally bring PV into the point of maturity, where it will be able to compete alone (without subsidies) on the energy market. The point where PV will be price competitive is called grid parity. We are approaching to grid parity quite fast, actually in the south of the EU, where there is more sun, grid parity is already on the threshold PVP without state subsidies have already begun to spring up.

PV has achieved exceptional results not only in terms of price competitiveness, but also in terms of installed PV power and related economic and environmental achievements - actually much more than the PV market actors had dear to announce. Therefore when talking about PV incentives policy (e.g. FIT cuts) we should always have in mind all the findings above. They of course can and even must be questioned again and in turn THIS is what can and must be the primary basis to set PV incentives policy or to review its adequacy.

\section{References}

2020 Targets. Retrieved August 23, 2013, from http://www.prosun.org/en/sustainable-eu-solar/energy-targets/2020-targets.html

Barteau, M. A. (n.d.). Prospectives on Energy. Retrieved November 25, 2009, from http://www.wilmapco.org/Our_Town/Mark_ Barteau.pdf

Brundtland Commission. (n.d.). In Wikipedia. Retrieved Septembra 10, 2009, from http://en.wikipedia.org/wiki/Brundtland_Commission

CdTe PV - Leading the Way to Sustainable Solar Energy. Retrieved August 23, 2013, from http://oursocialmedia.com/thin-film/cdte-pvleading-the-way-to-sustainable-solar-energy/

The components of GPI. Retrieved July 16, 2013, from http://genuineprogress.wordpress.com/the-components-of-gpi/

Concentrating solar power. (n.d.). In Wikipedia. Retrieved November 25, 2009, from http://en.wikipedia.org/wiki/Concentrated solar_power

Country maps. Retrieved September 12, 2013, from http://re.jrc.ec.europa.eu/pvgis/cmaps/eur.htm

Declarations and Reservations by Parties - Kyoto Protocol. Retrieved August 23, 2013, from http://unfccc.int/kyoto_protocol/status_of_ ratification/items/5424.php

DIRECTIVE 2009/28/EC OF THE EUROPEAN PARLIAMENT AND OF THE COUNCIL of 23 April 2009 on the promotion of the use of energy from renewable sources and amending and subsequently repealing Directives 2001/77/EC and 2003/30/EC. Official Journal of the European Union, 11, L 140, 16-62.

The EU climate and energy package. Retrieved August 23, 2013, from http://ec.europa.eu/clima/policies/package/index_en.htm

European Commission (2011). Renewables make the difference. Luxembourg: Publications Office of the European Union.

European Commission (2012). Energy roadmap 2050. Luxembourg: Publications Office of the European Union.

European Photovoltaic Industry Association (2012a). The Carbon Footprint. Retrieved May 3, 2013, from http://www.epia. org/index.php?elD=tx_nawsecuredl\&u=0\&file=/uploads/tx_epiafactsheets/110513_Fact_Sheet_on_the_Carbon_Footprint.pdf\&t= 1379580452\&hash=808a7fb6776bebcf107016bba3498746617a890f

European Photovoltaic Industry Association (2012b). The Energy Pay Back Time. Retrieved May 3, 2013, from http://www.epia.org/index.php?elD=tx_nawsecuredl\&u=0\&file=/uploads/tx_epiafactsheets/110513_Fact_Sheet_on_the_Energy_ Pay_Back_Time.pdf\&t=1379580452\&hash=5e689b9bfce16fc57e6d79c63658f2a50917ca2f

European Photovoltaic Industry Association (2012c). Job Creation. Sustainability of photovoltaci system. Retrieved May 3, 2013, from http://www.epia.org/index.php?elD=tx_nawsecuredl\&u=0\&file=/uploads/tx_epiafactsheets/Fact_Sheet_on_Job_Creation.pdf\&t=1 379580452\&hash=5997129ed6edf7754b78b1a5fb210d814173989d

European Photovoltaic Industry Association (2012d). PV PARITY Project: European consortium highlights competitiveness of Solar Photovoltaics (PV) in 11 EU countries. Retrieved May 3, 2013, from http://www.epia.org/index.php?elD=tx_nawsecuredl\&u $=0 \& f i l e=/$ uploads/tx_epiapressreleases/121126_PR1_PVPARITY_EN_Final.pdf\&t=1374755614\&hash=276a208314556729a7e4 8fcbc7ad5d70a521fe10

European Photovoltaic Industry Association (2012e). The Water Footprint. Retrieved May 3, 2013, from http://www.epia.org/index. php?elD=tx_nawsecuredl\&u=0\&file=/uploads/tx_epiafactsheets/Water_Footprint_Fact_Sheet.pdf\&t=1379580452\&hash=ee2ffc63 4c92b57ae8̄61f688e44752b2ef92a138

European Photovoltaic Industry Association (2013). GLOBAL MARKET OUTLOOK For Photovoltaics 2013-2017. S.I.: European Photovoltaic Industry Association.

European Photovoltaic Industry Association (2014a). MARKET REPORT 2013. S.I.: European Photovoltaic Industry Association.

European Photovoltaic Industry Association (2014b). GLOBAL MARKET OUTLOOK For Photovoltaics 2014-2018. S.I.: European Photovoltaic Industry Association.

External combustion engine. (n.d.). In Wikipedia. Retrieved November 25, 2009, from http://en.wikipedia.org/wiki/External_combustion_ engine

FAQs: Renewable energy. Retrieved June 6, 2014, from http://www.iea.org/aboutus/faqs/renewableenergy/Genuine Progress Indicator (GPI). Retrieved July 16, 2013, from http://genuineprogress.wordpress.com/about/genuineprogress. Retrieved July 16, 2013, from http://genuineprogress.wordpress.com/

Global solar resources. Retrieved August 23, 2013, from http://www.yoursunyourenergy.com/Global-solar-resources.htm 
Humanity's top ten problems. Retrieved June 13, 2013, from http://www.fnas.uwa.edu.au/research/problems

Johnson, G. (2009, september). Priklop na sonce [Plugging Into the Sun]. National Geographic, vol. (9), 30-53.

Key Facts \& Figures. Retrieved August 23, 2013, from http://www.epia.org/about-us/about-photovoltaics/key-facts-figures/

Kyoto Protocol. Retrieved August 23, 2013, from http://unfccc.int/kyoto_protocol/items/2830.php

Lenardič, D. (2009). Fotonapetostni sistemi [Photovoltaic systems]. Ljubjana: Agencija poti.

Nevada Solar One. Retrieved November 25, 2009, from http://www.acciona-na.com/About-Us/Our-Projects/U-S-/Nevada-SolarOne.aspx

Our plants. Retrieved June 7, 2013, from http://www.abengoasolar.com/web/en/nuestras_plantas/

Papler, D. (2012). Osnove uporabe solarnih toplotnih in fotonapetostnih sistemov [The principles of using solar thermal and photovoltaic systems]. Ljubaljana: Energetika marketing.

Ranking the renewables. Retrieved November 25, 2009, from http://ngm.nationalgeographic.com/2009/09/solar/ranking-renewables-map

Resnica o sončnih elektrarnah [The truth about solar power plants]. Retrieved May 3, 2013, from http://www.zsfi.si/novice/174-odprtopismo-resnica-o-soncnih-elektrarnah.html

Robotina d. 0. 0. (2013). Prodajno marketinška dokumentacija oddelka FV [Sell \& marketing documentation of the PV division] (internal publication). Hrpelje: Robotina d. 0. 0.

Samuelson, P. A., \& Nordhaus, W. D. (1998). Economics (16 th ed.; international ed.). S.I..: McGraw-Hill

Solar Energy Generating Systems. (n.d.). In Wikipedia. Retrieved November 25, 2009, from http://en.wikipedia.org/wiki/Solar_Energy_ Generating_Systems

Solar Energy. Retrieved August 23, 2013, from http://environment.nationalgeographic.com/environment/global-warming/solar-powerprofilel

Solar for Europe's future. Retrieved July 27, 2013, from http://www.prosun.org/en/sustainable-eu-solar/solar-for-europes-future.html

Solúcar Platform. Retrieved November 25, 2009, from http://www.abengoasolar.com/sites/solar/en/our projects/solucar/ps10/index.html

Status of Ratification of the Kyoto Protocol. Retrieved August 23, 2013, from http://unfccc.int/kyoto_protocol/status_of_ ratification/items/2613.php

Stirling Energy System Announces A New Division to Manufacture Suncatchers. Retrieved November 25, 2009, from http://www.solarthermalmagazine.com/stirling-energy-system-announces-a-new-division-to-manufacture-suncatchers/

Stirling Energy Systems set new world record for solar-to-grid conversion efficiency. Retrieved November 25, 2009, from http://www.sandia.gov/news/resources/releases/2008/solargrid.html

Stirling engine. (n.d.). In Wikipedia. Retrieved November 25, 2009, from http://en.wikipedia.org/wiki/Stirling_motor\#Applications

Sun. Retrieved November 25, 2009, from http://www.acciona-na.com/The-Big-Picture/Sun/Sun-101.aspx

Suncatcher. Retrieved November 25, 2009, from http://www.stirlingenergy.com/index.htm

Sustainable development. (n.d.). In Wikipedia. Retrieved September 10, 2009, from http://en.wikipedia.org/wiki/Sustainable_ development

Svijet nikad nije bio bogat kao te godine [The world has never been as reach as that year]. Retrieved July 16, 2013, from http://www.tportal.hr/vijesti/svijet/274695/Svijet-nikad-nije-bio-bogat-kao-te-

godine.html?fb action ids=10200658330994869\&fb_action_types=og.likes\&fb_source=other multiline\&action object map=\%7B \%2210200658330994869\%22\%3A206735192783493\%7D\&action_type_map=0\%7B\%2210200658330994869\%22\%3A \%220g.lik es\%22\%7D\&action_ref_map=\%5B\%5D

Tajnikar, M., Brščič, B., \& Bukvič, V. (1998). Upravljalska ekonomika [Management economics] (1. ed.). Ljubljana: Ekonomska fakulteta.

Wizard Power. Retrieved November 25, 2009, from http://www.wizardpower.com.au/index.php?option=com_content\&task=view\&id= $17 \&$ Itemid $=33$

Zalar, T. (2013). Pomen fotovoltaike za trajnostni razvoj [The role of photovoltaics for sustainable development]. Master's thesis, University of Ljubljana, Faculty of Economics, Ljubljana, Slovenia. 